\title{
Data for hygrothermal simulation of Scottish masonry buildings
}

\author{
P.F.G.Banfill \\ School of Energy, Geoscience, Infrastructure and Society, Heriot-Watt University, Edinburgh, UK
}

\begin{abstract}
To facilitate hygrothermal simulation of Scottish traditional masonry, values of relevant material properties have been determined for the following materials: Natural hydraulic lime mortars (NHL2, NHL3.5 and NHL5) and a hot-mixed lime mortar in both the uncarbonated and carbonated states, an earth mortar, three building stones in current production and three building stones used historically but no longer in production. This is the first time such data have been brought together.
\end{abstract}

Peer-review under the responsibility of the organizing committee of the ICMB21.

Keywords: hygrothermal properties; masonry; sandstone; granite; lime mortar

\begin{tabular}{|ll|}
\hline Nomenclature \\
$\rho_{0}$ & Dry density $\left(\mathrm{kg} / \mathrm{m}^{3}\right)$ \\
$\rho_{\text {sat }}$ & Saturated density $\left(\mathrm{kg} / \mathrm{m}^{3}\right)$ \\
$\theta_{\text {sat }}$ & Moisture content at saturation $\left(\mathrm{m}^{3} / \mathrm{m}^{3}\right)$ \\
$\theta_{\text {go }}$ & Moisture content at $90 \%$ relative humidity $\left(\mathrm{m}^{3} / \mathrm{m}^{3}\right)$ \\
$\theta_{\text {MIP }}$ & Porosity by mercury intrusion $\left(\mathrm{m}^{3} / \mathrm{m}^{3}\right)$ \\
$\lambda_{0}$ & Dry thermal conductivity $(\mathrm{Wm} / \mathrm{K})$ \\
$\lambda_{\text {sat }}$ & Saturated thermal conductivity $(\mathrm{Wm} / \mathrm{K})$ \\
$\mu_{\text {dry }}$ & Dry cup vapour diffusion resistance factor (dimensionless) \\
$\mu_{\text {wet }}$ & Wet cup vapour diffusion resistance factor (dimensionless) \\
$W_{\mathrm{A}}$ & Water absorption coefficient $\left(\mathrm{kg} / \mathrm{m}^{2} \sqrt{\text { sec }}\right)$ \\
\hline
\end{tabular}

\section{Introduction/Background}

Traditional solid masonry walls breathe and this moisture transfer ability determines their performance and durability. To prevent accelerated material deterioration, understanding the hygrothermal impacts of building alterations such as retrofitting thermal insulation is critical for structures exposed to significant rain and/or indoor vapour. Hygrothermal simulation software enables designers to assess the impact of insulation retrofits on solid walls and avoid negative effects [1] but information on the hygrothermal properties relevant to Scottish masonry that are needed for simulation is not available. The investigation [2] summarised here aimed to contribute to a dataset of material properties that can be used by designers to ensure that retrofits meet the needs of traditional buildings as well as achieve energy efficiency.

\section{Material selection, specimen preparation and testing}

Six building stones representative of Scottish masonry were selected. Of those in current production, Hazeldean sandstone, Locharbriggs sandstone and Scottish whinstone were obtained from suppliers. Of those no longer available, Crathes granodiorite (obtained from a roadstone quarry) closely matches Rubislaw granite (which was widely used in Aberdeen), and Craigleith sandstone (Edinburgh) and Giffnock sandstone (Glasgow) were obtained from conservation projects in progress. Mortar was mixed in the laboratory using natural hydraulic lime (NHL2, NHL3.5 and NHL5, St Astier, France) and concrete sand (1:3 by volume). Hot-mixed lime mortar and earth mortar were collected from an active work site in Dunbar, East Lothian. Specimens were cut or cast into $100 \mathrm{~mm}$ cubes and 90x120x12mm tiles. Lime mortar specimens were carbonated in a controlled environment chamber at $20^{\circ} \mathrm{C}, 60 \%$ relative humidity and $600 \mathrm{ppm} \mathrm{CO}_{2}$. All materials were tested singly, not as layered composites.

Density was determined by displacement of water. Thermal conductivity was determined in both the dry and saturated conditions using the Thermtest TLS-100 instrument (Thermtest inc, Fredericton, Canada) and the thermal probe method to ASTM D5334-14 [3]. Water vapour diffusion resistance factor was determined by both dry cup and wet cup methods according to BS EN ISO 12572:2001 [4]. Water absorption coefficient was determined gravimetrically according to BS EN ISO 15148:2002 [5]. 
ICMB21

Hygroscopic sorption curves were determined according to BS EN ISO 12571:2013 [6], using relative humidities of 33, 53, 75, 85,93 and $100 \%$. Porosity and pore size distribution were determined by mercury intrusion in a Quantachrome PoreMaster 33 .

\section{Results}

Variously 1, 3, 4 or 5 specimens were tested for each property (Table 1). The earth mortar disintegrated on contact with water so the saturated density, moisture content at saturation, saturated thermal conductivity and water absorption coefficient were not determined. Additionally, it collapsed under the high intruding mercury pressure needed for the fine pores. The sorption-desorption curves all showed hysteresis with the moisture content on the downcurve higher than that on the upcurve and because their form is the same for all materials, Table 1 shows the moisture contents by volume $\left(\theta_{90}\right)$ reached at $90 \%$ relative humidity, interpolated from the upcurves but Scottish whinstone is omitted because of an experimental problem. Table 1 also shows the $90 \%$ confidence limits, estimated from the variability between measurements on replicate specimens. It should be noted that the interval for water absorption coefficient is given as a percentage of the mean value and that for water vapour diffusion resistance is not constant because the resistance is obtained by dividing the permeability of still air by the permeability of the material.

Table 1. Summary of numerical properties of masonry materials (means of $3,4^{\S}$ or $5^{\wedge}$ specimens, or single* determinations).

\begin{tabular}{|c|c|c|c|c|c|c|c|c|c|c|}
\hline Material & $\rho_{0}$ & $\rho_{\text {sat }}$ & $\theta_{\text {sat }}$ & $\lambda_{0}$ & $\lambda_{\text {sat }}$ & $\mu_{\text {dry }}$ & $\mu_{\mathrm{wet}}$ & $W_{\mathrm{A}}$ & $\theta_{90}$ & $\theta_{\text {MIP }}$ \\
\hline $90 \%$ Confidence interval & \pm 20 & \pm 20 & \pm 0.004 & \pm 0.75 & \pm 0.75 & See below & See below & $\pm 30 \%$ & \pm 0.0015 & - \\
\hline Hazeldean sandstone & 2275 & 2300 & 0.097 & 1.7 & 4.0 & $37 \pm 5^{\wedge}$ & $22 \pm 7^{\wedge}$ & 0.11 & 0.0029 & $0.17 *$ \\
\hline Locharbriggs sandstone & 2200 & 2275 & 0.14 & 1.4 & 3.4 & $30 \pm 3^{\wedge}$ & $17 \pm 4^{\wedge}$ & 0.086 & 0.015 & $0.15^{*}$ \\
\hline Craigleith sandstone & 2450 & 2500 & 0.045 & 1.7 & 4.2 & $120 \pm 60^{\wedge}$ & $63 \pm 10$ & 0.0081 & 0.013 & $0.083 *$ \\
\hline Giffnock sandstone & 2200 & 2300 & 0.13 & 1.1 & 4.2 & $37 \pm 5^{\S}$ & $18 \pm 4^{\wedge}$ & 0.073 & 0.023 & $0.20 *$ \\
\hline Crathes granodiorite & 2650 & 2650 & 0.006 & 2.1 & 2.8 & $1100 \pm 800^{\wedge}$ & $500 \pm 150^{\wedge}$ & 0.0011 & 0.0031 & $0.011 *$ \\
\hline Scottish whinstone & 2925 & 2925 & 0.006 & 1.4 & 2.4 & $1400 \pm 900^{\wedge}$ & $600 \pm 200^{\wedge}$ & 0.00022 & - & $0.019 *$ \\
\hline NHL2 mortar uncarbonated & 1900 & 2100 & 0.20 & 0.7 & 1.2 & $17 \pm 2^{\S}$ & $9 \pm 2$ & 0.21 & 0.025 & $0.19 *$ \\
\hline NHL2 mortar carbonated & 1950 & 2125 & 0.18 & 0.6 & 1.0 & $15 \pm 2^{\S}$ & $8 \pm 2^{\S}$ & 0.26 & 0.015 & $0.22 *$ \\
\hline NHL3.5 mortar uncarb'd & 1800 & 2000 & 0.18 & 0.7 & 1.3 & $16 \pm 2^{\S}$ & $8 \pm 2$ & 0.11 & 0.027 & $0.24 *$ \\
\hline NHL3.5 mortar carbonated & 1800 & 2000 & 0.19 & 0.7 & 1.2 & $16 \pm 2^{\S}$ & $7 \pm 2^{\S}$ & 0.20 & 0.015 & $0.28 *$ \\
\hline NHL5 mortar uncarbonated & 1950 & 2150 & 0.20 & 0.9 & 1.8 & $19 \pm 2$ & $9 \pm 2$ & 0.10 & 0.031 & $0.24 *$ \\
\hline NHL5 mortar carbonated & 1975 & 2175 & 0.20 & 0.7 & 1.3 & $25 \pm 3$ & $11 \pm 2$ & 0.32 & 0.014 & $0.25 *$ \\
\hline Hot-mix mortar uncarb'd & 1750 & 1950 & 0.36 & 0.2 & 0.8 & $23 \pm 3^{\S}$ & $14 \pm 2^{\S}$ & 0.28 & 0.026 & $0.31^{*}$ \\
\hline Hot-mix mortar carbonated & 1850 & 2000 & 0.31 & 0.2 & 0.7 & $23 \pm 3^{\S}$ & $13 \pm 2^{\wedge}$ & 0.36 & 0.024 & $0.30 *$ \\
\hline Earth mortar & 2000 & - & - & 0.2 & - & $29 \pm 3$ & $12 \pm 2^{\S}$ & - & 0.05 & - \\
\hline
\end{tabular}

The general trends within the measured data are consistent: more porous materials are less dense, have lower thermal conductivity, higher water absorption and lower vapour diffusion resistance. The values are generally within the range of values for similar materials, reported by a number of international sources [2].

\section{Conclusion}

The hygrothermal properties of a range of building stones, natural hydraulic lime mortars and a hot-mixed lime mortar in both the uncarbonated and carbonated states, and an earth mortar, relevant to traditional masonry construction in Scotland are given.

\section{References}

[1] Little, J., Ferraro, C., Arregi, B. (2015). Assessing risks in insulation retrofits using hygrothermal software tools. Technical Report 15, Edinburgh, Historic Environment Scotland.

[2] Banfill, P.F.G. (2021). Hygrothermal simulation of building performance: data for Scottish masonry materials. Materials and Structures, in communication.

[3] ASTM. (2014). Standard test method for determination of thermal conductivity of soil and soft rock by thermal needle probe procedure. D5334-14, West Conshohocken, USA, ASTM International.

[4] BSI. (2001). Hygrothermal performance of building materials and products - Determination of water vapour transmission properties. BS EN ISO $12572: 2001$ London, British Standards Institution.

[5] BSI. (2002). Hygrothermal performance of building materials and products - Determination of water absorption coefficient by partial immersion. BS EN ISO 15148:2002 London, British Standards Institution.

[6] BSI. (2013). Hygrothermal performance of building materials and products - Determination of hygroscopic sorption properties. BS EN ISO 12571:2013 London, British Standards Institution. 